\title{
Reflections on Health Tourism and Cross-Border Health Care
}

\author{
Isabel Pirillo ${ }^{1 *}$, Francesco Amenta ${ }^{1,2}$ \\ ${ }^{1}$ Centre of Telemedicine and Telepharmacy, University of Camerino, Camerino, Italy \\ ${ }^{2}$ International Radio Medical Centre (C.I.R.M.), Roma, Italy
}

Corresponding Author: Isabel Pirillo, PhD, Centre of Telemedicine and Telepharmacy, University of Camerino, 62032

Camerino (MC) Italy. Tel: 00390737403326, Email: isabel.pirillo@unicam.it

Received November 2017, 2017; Accepted November 18, 2017; Online Published January 20, 2018

Citation: Pirillo I, Amenta F. Reflections on health tourism and cross-border health care. Int J Travel Med Glob Health. 2018;6(2):84-85. doi:10.15171/ ijtmgh.2018.16.

\section{Dear Editor,}

Medical tourism is recognized as one of the oldest forms of tourism to obtain medical services and health care of high quality. ${ }^{1}$ It requires the realization of several services, such as coordination and cooperation between countries, ${ }^{2}$ to safeguard the right of access to quality care, the right to reimbursement for medical services, and the privacy of patients.

A 2008 report forecasted that the number of medical tourists would rise from 750000 in 2007 to between 5.25 and 6.25 million by 2010 , and to between 10.5 and 23.2 million by $2017 .{ }^{3}$ Patients are informed consumers claiming the right to choose healthcare providers, including professionals, outside their national borders. In this research, patients are supported and encouraged by several factors, including use of the Internet and information about services and health professionals. Health tourism is under development in different countries ${ }^{4}$ and is spreading across the European Union as an example of cross-border healthcare.

Directive 2011/24/EU, ${ }^{5,6}$ which has considered various aspects of cross-border care, recognizes the right of patients to receive healthcare in another member state and the right to reimbursement for medical care. The aim of this directive is to provide more legal certainties about the right to care in other European States. The directive is structured in three main areas: (1) identifying the member state responsible for ensuring observance of health care principles; (2) specifying the rights of patients to health care in another state; and (3) establishing a framework for European cooperation.

Two important aspects of medical tourism and crossborder healthcare are the patient's right to receive complete information and the patient's right to protection of privacy and confidentiality. ${ }^{6}$ To help patients make conscious choices, the country where treatment is obtained should ensure that all patients from other member states receive, on request, information on all safety and quality standards enforced in its territory. This includes the prices and availability of health care options, information on health care outcomes, and details of health insurance coverage, other personal means, or collective protection according to professional liability. ${ }^{7}$

Moreover, patients should be guaranteed a level of coverage for health care costs which is at least equivalent to what would have been accorded them in their country of origin.

Medical tourism and cross-border care in Europe should be considered as an opportunity to ensure continuity of care and access, if not provided in the countries of origin, to quality care in other member states. For such reason, cross-border care should also be implemented through the greater diffusion of specific healthcare initiatives.

These should include the greater diffusion among health professionals of medical informatics instruments such as EHCs (electronic health cards), telemedicine services, and other technology to treat or monitor patients remotely by $\mathrm{ICTs}^{8}$ (information and communication technologies) as well as e-health and telemedicine education at university and postuniversity levels.

Paradoxically, technology in this field is largely available. What is still missing to some extent are the legal clarity, awareness, and education that should be pursued for the benefit of citizens and their health protection.

\section{Authors' Contributions}

PI: conception of the study and drafting of article and AF: final approval.

\section{Conflict of Interest Disclosures None.}




\section{Ethical Approval}

Not applicable.

\section{Funding/Support}

Dr Isabel Pirillo is a recipient of a PostDoc grant from Camerino University.

\section{References}

1. Amouzagar S, Mojaradi Z, Izanloo A, Beikzadeh S, Milani M. Qualitative Examination of Health Tourism and Its Challenges. Int J Travel Med Glob Health. 2016;4(3):88-91. doi:10.21859/ ijtmgh-040304.

2. Rokni L, Rezaei Mahmoudi M. Codes as Barriers of Marketing Health Tourism. International Congress of Advances in Hospitality and Tourism Marketing and Management; Turkey; 2011:630-634

3. Deloitte Development LLC. Medical Tourism: Consumers in
Search of Value. Washington DC: Deloitte Center for Health Solutions; 2008

4. Jabbari A, Delgoshaei B, Mardani R, Tabibi SJ. Medical tourism in Iran: Issues and challenges. J Educ Health Promot. 2012;1:39. doi:10.4103/2277-9531.104809.

5. European Union. Directive 2011/24/EU of the European Parliament and of the Council of 9 March 2011 on the application of patients' rights in cross-border healthcare. Off J Eur Union. 2011. http:// data.europa.eu/eli/dir/2011/24/oj.

6. Pirillo I, Amenta F, Sirignano A, Ricci G. Cross-border healthcare: Implementation of Directive 2011/24/EU and National Contact Point in Italy. Travel Med Infect Dis. 2017;18:79-80. doi:10.1016/j. tmaid.2017.06.005.

7. Den Exter A, Hervey T. European Union Health Law: Treaties and Legislation. Maklu Publishers; 2012.

8. Rezaei-Hachesu P, Safdari R, Ghazisaeedi M, Samad-Soltani T. The Applications of Health Informatics in Medical Tourism Industry of Iran. Iran J Public Health. 2017;46(8):1147-1148. 